Article

OZASLAN, C. ${ }^{1 *}$

HÜSEYIN, E. ${ }^{2}$

FAROOQ, S. ${ }^{3}$

ONEN, H. ${ }^{4}$

* Corresponding author:

<cumaliz@yahoo.com>

Received: April 7,2017

Approved: July 24, 2017

Planta Daninha 2018; v36:e018178209

Copyright: This is an open-access article distributed under the terms of the Creative Commons Attribution License, which permits unrestricted use, distribution, and reproduction in any medium, provided that the original author and source are credited.

\section{New Records of Microfungi and Chromista From Anatolian Peninsula of TURKey}

\author{
Novos Registros de Fungos da Península Anatólica da Turquia
}

\begin{abstract}
This article presents new records of fungi and downy mildews in Turkey on different weeds of agrophytocoenosis. These records include Plectosphaerella alismatis (Oudem.) A.J.L. Phillips, Carlucci \& M.L. Raimondo (on Alisma plantago-aquatica L.), Pyricularia grisea Sacc. (on Setaria viridis (L.) P. Beauv.), Phakopsora artemisiae Hirats. (on Artemisia dracunculus L.), Puccinia rubefaciens Johanson (on Galium sp.), Ustilago trichophora (Link) Kunze (on Echinochloa crus-galli (L.) P. Beauv.), Peronospora astragalina Syd. (on Astragalus homosus L.) and P. myagri Mayor (on Myagrum perfoliatum L.). Plectosphaerella and Phakopsora as generic level and others as species are new records from Turkey. Description and illustrations of the identified fungi are presented, which all are based on Turkish specimens. The identified fungi could be potential biological control agents; however, detailed studies are needed in this regard.
\end{abstract}

Keywords: Ascomycota, Basidiomycota, Oomycota, taxonomy, weeds, Turkey.

RESUMO - Este artigo apresenta novos registros de fungos na Turquia sobre diferentes plantas daninhas da agrofitocenose. Esses registros incluem Plectosphaerella alismatis (Oudem.) A.J.L. Phillips, Carlucci e M.L. Raimondo (em Alisma plantago-aquatica L.), Pyricularia grisea Sacc. (em Setaria viridis (L.) P. Beauv.), Phakopsora artemisiae Hirats. (em Artemisia dracunculus L.), Puccinia rubefaciens Johanson (em Galium sp.), Ustilago trichophora (Link) Kunze (em Echinochloa crus-galli (L.) P.Beauv.), Peronospora astragalina Syd. (em Astragalus homosus L.) e P. myagri Mayor (em Myagrum perfoliatum L.). Plectosphaerella e Phakopsora como nível genérico e outros como espécies, originando novos registros da Turquia. A descrição e a ilustração dos fungos identificados são apresentadas, sendo todos baseados em espécimes turcos. Os fungos identificados podem ser potenciais agentes de controle biológico, porém estudos detalhados são necessários nesse sentido.

Palavras-chave: Ascomycota, Basidiomycota, Oomycota, taxonomia, plantas daninhas, Turquia.

\section{INTRODUCTION}

Weeds are the major handicaps in agricultural ecosystems which decrease crop productivity and incur massive management costs (Zimdahl, 2013). The occurrence of phytopathogenic fungi and other microorganisms on weed species are important because of increasing interest in biological control. Moreover, increasing cases of herbicide resistant weeds and undue interventions of

1 Dicle University, Faculty of Agriculture, Diyarbakir, Turkey; ${ }^{2}$ Ahi Evran University, Sciences and Arts Faculty, Kirsehir, Turkey; ${ }^{3}$ Department of Plant Protection, Harran University, Sanliurfa, Turkey; ${ }^{4}$ Gaziosmanpasa University, Faculty of Agriculture, Tokat, Turkey. 
herbicides in cultural ecosystems have made it inevitable to find reliable, alternative weed management approaches. The use of microorganisms in classical biological control of different weed species has increased since last decades. Some of these fungi and other microorganisms are potential biological control agents of these weed species (Kiss, 2003; Rector et al., 2006). There are some reports from Turkey denoting the presence of fungal plant pathogens on different weed species (Göbelez, 1963,1964; Ercis and Iren, 1993; Tepe and Özrenk, 1999; Bahcecioglu and Gjaerum, 2003; Kavak, 2003; Sert and Sümbül, 2003; Kirbag, 2004; Sert, 2009; Tunali et al., 2009; Erdogdu et al., 2010; Ekici et al., 2012; Erdogdu and Hüseyin, 2013; Özaslan et al., 2013; Kavak and Bilgili, 2015; Özaslan et al., 2015). Therefore, determination, identification and reporting of new occurrence records of fungal pathogens and other microorganisms are of great importance. These reports assist ecologists, mycologists and weed scientists to assess the biogeography and ecology of hosts and pathogens (Dugan and Glawe, 2007). Moreover, these reports are of prime importance for development of biological control programs against different weed species present in a particular region. Therefore, we have been aimed at determining the new fungal and Chromista pathogens on different weed species prevailing in different provinces of Turkey in this study.

\section{MATERIALS AND METHODS}

Samples of the fungi were collected from various weed species during periodical mycological surveys conducted in different localities of Turkey, through 2012 to 2015 . Microscopic studies were carried out on slides prepared in distilled water. Photomicrographs were captured by means of Olympus BX 53 research microscope supplied with Olympus DP 22 digi-CAM (Japan) and Axio imager 2 equipped with Nomarski differential interference contrast optics. The fungi were identified using the handbooks and other publications (Shvartsman, 1960; Mayor, 1962; Uljanishchev, 1968; Shvartsman, 1973; Kuprevich, 1975; Uljanishchev, 1978; Ellis and Ellis, 1985; Uljanishchev et al., 1985; Mordue, 1995; Braun, 1998; Azbukina, 2005; Vánky, 2012) by examining the lesions formed in the plant tissue, conidial structure, conidioforun branching, conidium structure, conidium shape, color and size of resting organ. The host weed species' specimens were prepared according to established herbarium techniques. The host weed species were identified using the "Flora of Turkey and East Aegean Islands" (Davis, 1965-1985). Taxa, families, and author citations were spelled according to Kirk and Ansell (1993), and Fungorum (2016). All specimens have been deposited in the Mycological Collection of Dicle University, Diyarbakir (Faculty of Agriculture, Department of Plant Protection).

\section{RESULTS AND DISCUSSION}

Systematic status of the recorded taxa belonging to Ascomycota, Basidiomycota and Chromista, and their description, photos of symptoms, and photomicrographs based on Turkish samples are provided below.

Fungi

Ascomycota Caval.-Sm.

Plectosphaerellaceae W. Gams, Summerb. \& Zare

Plectosphaerella alismatis (Oudem.) A.J.L. Phillips, Carlucci \& M.L. Raimondo. Carlucci et al., 2012: 39.

[Syn. Septoria alismatis Oudem., Arch. néerl. Sci. 8:346 (1873); Ascochyta alismatis (Oudem.) Trail, Scott. Natural., N.S. 3 ('9'):188 (1887); Rhynchosporium alismatis (Oudem.) Davis, Trans. Wis. Acad. Sci. Arts Lett. 20:420 (1922); Didymaria alismatis (Oudem.) Davis, Parasitic Fungi of Wisconsin: 103 (1942); Spermosporina alismatis (Oudem.) U. Braun, Cryptog. bot. 4(1): 111 (1993); Plectosporium alismatis (Oudem.) W.M. Pitt, W. Gams \& U. Braun, in Pitt, Goodwin, Ash, Cother \& Cother, Mycol. Res. 108 (7):779 (2004)] (Figure 1). 


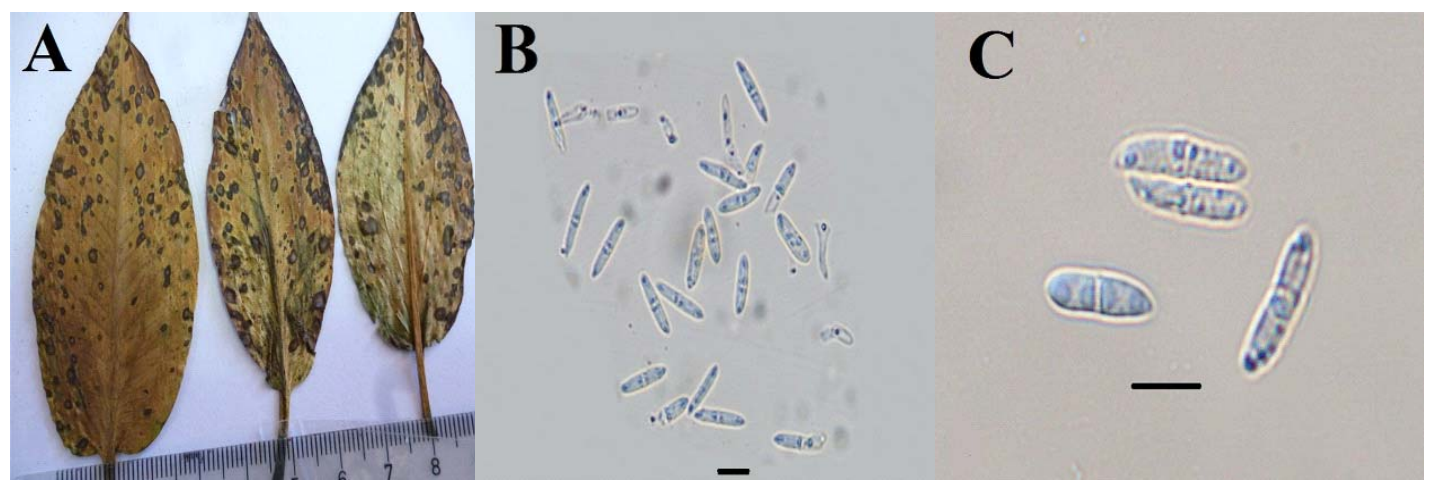

Figure 1 - Plectosphaerella alismatis. A: Symptoms. B-C: Conidia. Bars: B-C $10 \mu \mathrm{m}$.

Leaf spots numerous, amphigenous, subcircular to somewhat angular-irregular, 0.5-5 mm diam., brown, later center pale, often confluent, numerous at the edges. Colonies amphigenous, effuse, greyish white. Conidia solitary, narrow-ellipsoid, subcylindric, subclavate, fusiform, $15-20 \times 2-3(-4.5) \mu \mathrm{m}, 0-2$-septate, mostly 1-septate, rarely slightly constricted at the septa, hyaline, smooth, apex acuminate or rounded, base rounded or usually somewhat attenuated.

Specimen examined: In paddy field, on the living leaves of Alisma plantago-aquatica L. (Alismataceae), Turkey, Siirt Province, Karaca Village, 3807’09" N, 4201'59" E, 1300 m, September 18, 2014. CÖ 201405.

Specimen of $P$. alismatis from Turkey has conidia similar in size to those described by Carlucci et al. (2012), where conidia are $13-19.5 \times 2.5-3 \mu \mathrm{m}$, mostly septate.

\section{Pyriculariaceae Klaubauf, Lebrun \& Crous}

\section{Pyricularia grisea Cooke ex Sacc.}

Saccardo 1886:217.

[Syn. Trichothecium griseum Cooke, in Ravenel, Amer. Fungi: no. 580 (1882); Dactylaria grisea (Sacc.) Shirai, in Miyake, J. Coll. Agric. imp. Univ. Tokyo 2:262 (1910); Ceratosphaeria grisea T.T. Hebert, Phytopathology 61(1):86 (1971); Magnaporthe grisea (T.T. Hebert) M.E. Barr, Mycologia 69 (5):954 (1977); Phragmoporthe grisea (T.T. Hebert) M. Monod, Beih. Sydowia 9: 153 (1983)]. Anamorphic Magnaporthe R.A. Krause \& R.K. Webster (Figure 2).

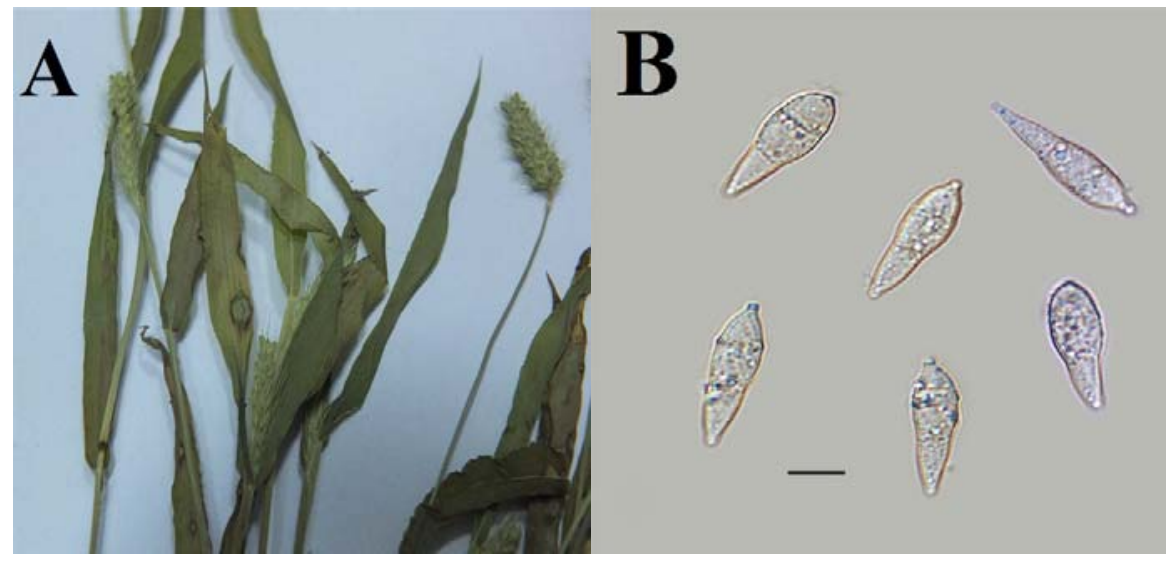

Figure 2 - Pyricularia grisea. A: Symptoms. B: Conidia. Bars: B $15 \mu \mathrm{m}$.

Leaf spots round or oblong, $0.5-2.5 \mathrm{~cm}$ across, whitish, light gray with a reddish-brown border, confluent. Caespituli hypophyllous, grey, single or in loose bundles. Conidiophores simple, septate, tapering at the top, sinuate, $75-85 \times 4-4.5 \mu \mathrm{m}$. Conidia gray, obclavate or pyriform, base acuminate, 2-3-septate, mostly 2-septate, (20-) 22-25 (-27) x 7.5-10 $\mu \mathrm{m}$. 
Specimen examined: In vegetable field tomato garden, on the living leaves of Setaria viridis (L.)

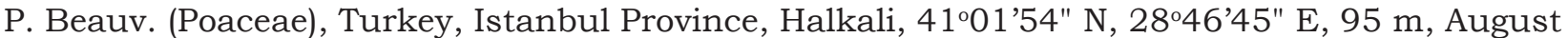
12, 2013. CÖ 201319.

Conidia of $P$. grisea recorded from Turkey have mostly 2 septa, (20-)22 - 25(-27) x 7.5-10 $\mu \mathrm{m}$. The size of our samples differs from the type material by their larger conidia and number of septa, the conidia of type specimen have 3 septa, $18 \times 9 \mu \mathrm{m}$ (Saccardo, 1886). According to Shvartsman et al. (1973) conidia 18-22 x 7-9 $\mu \mathrm{m}, 2-3$-septate, which is slightly smaller than those found in the Turkish specimen.

\section{Basidiomycota R.T. Moore}

\section{Phakopsoraceae Cummins \& Hirats. f.}

\section{Phakopsora artemisiae Hirats. f.}

Mundkur (1943).

[Syn. Physopella artemisiae (Hirats.f.) Azbukina, Nov. Sist. Niz. Rast. 7:227 (1970)] (Figure 3).

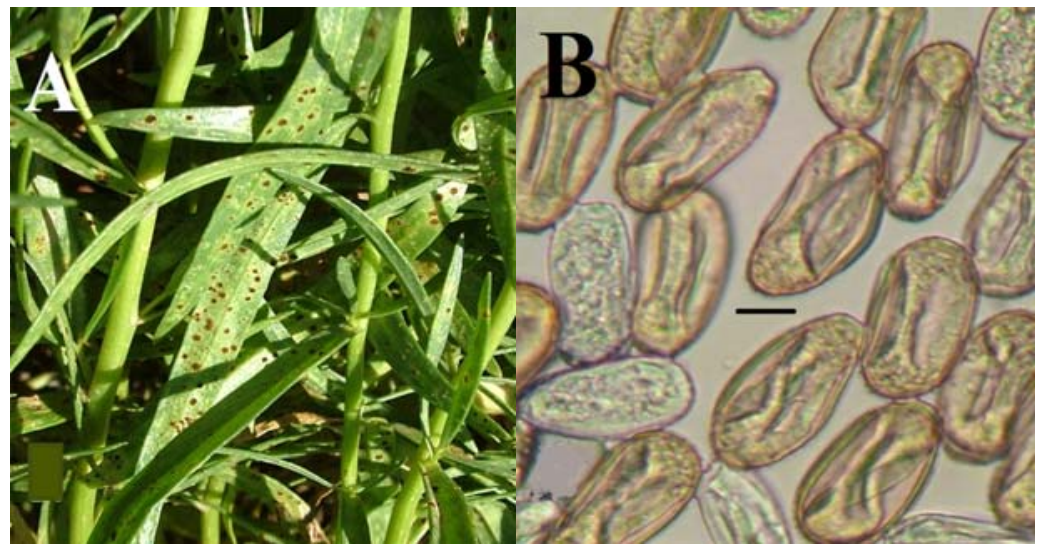

Figure 3 - Phakopsora artemisiae. A: Symptoms. B: Teliospores. Bars: B $10 \mu \mathrm{m}$.

Pycnia and aecia unknown. Uredinia amphigenous, scattered or in small group, rounded, yellow, at first covered by epidermis, later rupturing with a central pore. Paraphyses numerous, capitate, capitate-clavate, hyaline, 35-40 $\mu \mathrm{m}$ long. Urediniospores globoid, ellipsoid, oviod or obovoid, $22-40 \times 18-22 \mu \mathrm{m}$; wall hyaline, minutely shortly echinulate, $1.5 \mu \mathrm{m}$ thick. Telia amphigenous, occasionally hypophyllous, scattered or in groups, yellowish-brown or brown, 0.2-0.5 mm diam. Teliospores in chains, lenticular, 28-35 x 14-17 $\mu \mathrm{m}$; wall yellow or brown, 1.2-1.5 $\mu \mathrm{m}$ thick, of the terminal teliospores apex thickened up to 3.5-4.0 $\mu \mathrm{m}$.

Specimen examined: In vegetable field tarragon garden, on the living leaves of Artemisia dracunculus L. (Asteraceae), Turkey, Sanliurfa Province, 371’이" N, 3857’14" E, 570 m, July 10, 2012. CÖ 201224.

P. artemisiae from Japan has urediniospores 23.4-38 x 16-25 $\mu \mathrm{m}$ and teliospores 19-33 x 13-18 $\mu \mathrm{m}$ (Hiratsuka et al., 1992). The specimen of this species collected and identified from Turkey has a little long teliospores (28-35 x 14-17 $\mu \mathrm{m})$.

\section{Pucciniaceae Chevall.}

\section{Puccinia rubefaciens Johanson}

Saccardo 1888: 680.

[Syn. Dicaeoma rhytismodes (Johanson) Kuntze, Revis. gen. pl. (Leipzig) 3(2):470 (1898); D. rubefaciens (Johanson) Kuntze, Revis. gen. pl. (Leipzig) 3 (2):470 (1898); Micropuccinia rubefaciens 
(Johanson) Arthur \& H.S. Jacks., Bull. Torrey bot. Club 48:41 (1921); Leptopuccinia rubefaciens (Johanson) Syd., Annls mycol. 20 (3/4):121 (1922)] (Figure 4).

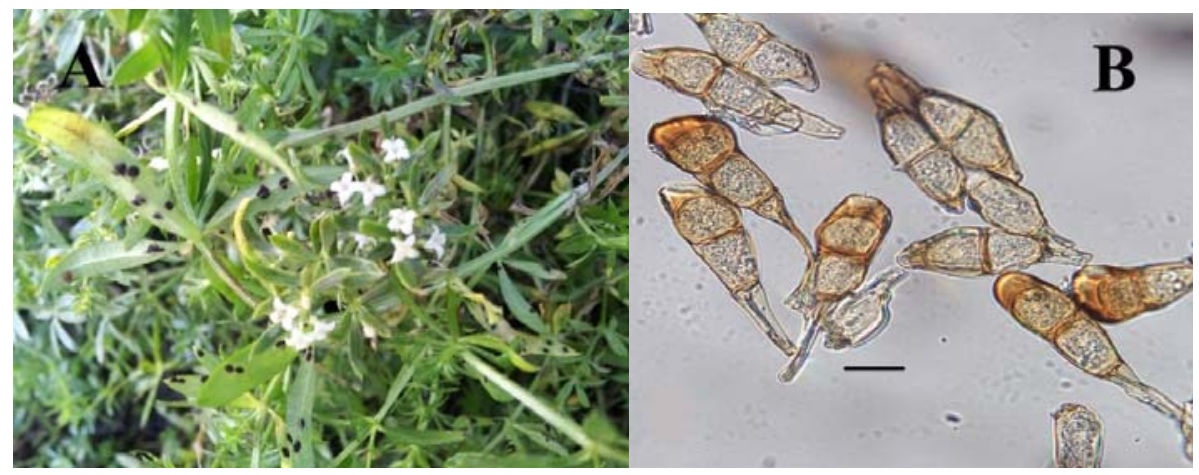

Figure 4 - Puccinia rubefaciens. A: Symptoms. B: Teliospores. Bars: $15 \mu \mathrm{m}$.

Pycnia, aecia and uredinia not seen. Telia on rounded or irregular reddish-purple or yellow spots, hypophyllous, rarely epiphyllous, sometimes on stems and sprouts, scattered, confluent, oblong, 1-3 mm long, blackish-brown or black, Teliospores oblong-clavate or clavate, (35-) 40$50 \times(17.5-) 20-22(-25) \mu \mathrm{m}$, constricted at the septum; wall dark brown, 1.5-2.0 $\mu \mathrm{m}$ thick, apex thickened up to $10 \mu \mathrm{m}$, smooth; pedicel hyaline, persistent, $25-30 \times 5-6 \mu \mathrm{m}$.

Specimen examined: In fallow land, on the living leaves of Galium sp. (Rubiaceae), Turkey, Artvin Province, Borçka District, 4578’11" N, 3772’85" E, 234 m, November 25, 2013. CÖ 201306

P. rubefaciens from Turkey differ from the type species (Saccardo, 1888:680, teliospores 30$53 \times 14-22 \mu \mathrm{m}$ ) and other literature data (Uljanishchev, 1978:251, teliospores 36-53 $\times 14-22 \mu \mathrm{m}$; Azbukina, 2005:366, teliospores 30-50(-53) $\times 14-22 \mu \mathrm{m})$, by slightly shorter and wider teliospores, (35-)40-50 × (17.5-)20-22(-25) $\mu \mathrm{m}$.

\section{Ustilaginaceae Tul. \& C. Tul.}

\section{Ustilago trichophora (Link) Kunze}

Saccardo 1888: 462

[Syn. Caeoma trichophorum Link, in Willdenow, Sp. pl., Edn 4 6(2):3 (1825); (Uredo) Ustilago trichophora (Link) Kunze, Flora, Regensburg 13:369 (1830); Ustilago sphaerogena Burrill, in Berlese, De Toni \& Fischer, Syll. fung. (Abellini) 7:468 (1888); Cintractia sphaerogena (Burrill) H.H. Hume, Proc. Iowa Acad. Sci. 9:233 (1902); Ustilago crus-galli Tracy \& Earle, Bull. Torrey bot. Club 22:175 (1895); Cintractia crus-galli (Tracy \& Earle) P. Magnus, Ber. dt. bot. Ges. 14:392 (1896); Ustilago trichophora (Link) Kunze var. crus-galli (Tracy \& Earle) Lavrov, Trudy Biol. Naucno- Issl. Inst. Tomsk. Gosud. Univ. 2:9 (extr.) (1936); Ustilago panici-frumentacei Brefeld, Unters. Gesammtgeb. Mykol. (Liepzig) 12:103 (1895); Ustilago trichophora (Link) Kunze var. pacifica Lavrov, Trudy biologicheskogo Nauchno-Issledovatel'skogo Instituta Tomskogo Gosudarstvennogo Universiteta 2:9 (extr.) (1936); Cintractia seymouriana P. Magnus, Ber. dt. bot. Ges. 14:217 (1896); Ustilago globigena Spegazzini, Anal. Mus. nac. Hist. nat. B. Aires 6:208 (1898) [1899]; Ustilago holubii Syd., Annls mycol. 33(3/4):230 (1935); Sphacelotheca almorae A. Krishna \& R. A. Singh, Indian J. Mycol. Plant Path. 10(2):177 (1980)] (Figure 5).

Sori forming moniliform bullate bodies on the leaves, inflorescences and stems, 3-30 mm diam. to $10 \mathrm{~cm}$ long swellings, covered by a inspid membrane composed of an inner, fungal layer and an outer layer of host origin, with expressly overgrown hairs. After the rupture of membrane powdery dark brown mass of spores is released. Spores light olivaceous-brown, globose, subglobose to ovoid, 7.5-10 x 7-9 $\mu \mathrm{m}$; wall 1.0-1.5 $\mu \mathrm{m}$ thick, sparsely to moderately densely, minutely verruculose or echinulate. 


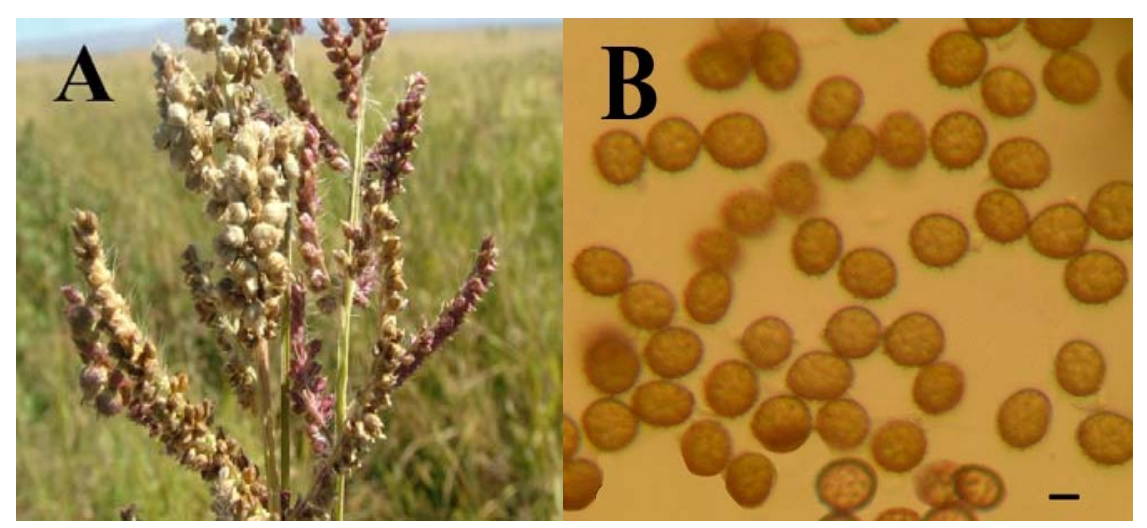

Figure 5 - Ustilago trichophora. A: Symptoms. B: Spores. Bars: $10 \mu \mathrm{m}$.

Specimen examined: In paddy field, on the living leaves, inflorescences and stems of Echinochloa crus-galli (L.) P. Beauv. (Poaceae), Turkey, Sanliurfa Province, Siverek District, 3959'31" N, 3707'45" E, 848 m, September 29, 2012. CÖ 201228; Siirt Province, Karacaköy District, 3807’09" N, 4201'59" E, 1038 m, October 1, 2012. CÖ 201296.

We measured the spores of $U$. trichophora as 7.5-10 x 7-9 $\mu \mathrm{m}$. According to Gutner (1941), spores 8 - $14 \mu \mathrm{m}$ diam.; Savulescu (1957: 574), 9-10 $\mu \mathrm{m}$ diam. or 9-12 x 7-10 $\mu \mathrm{m}$; Shvartsman

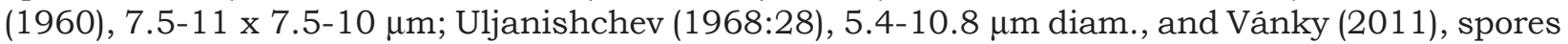
6-11 $\times 7-12 \mu \mathrm{m}$. Sizes of spores from Turkey is in the range indicated in the literature.

\section{Chromista}

Oomycota Arx

\section{Peronosporaceae de Bary}

Peronospora astragalina Syd. (Figure 6)

Saccardo 1972: 31.

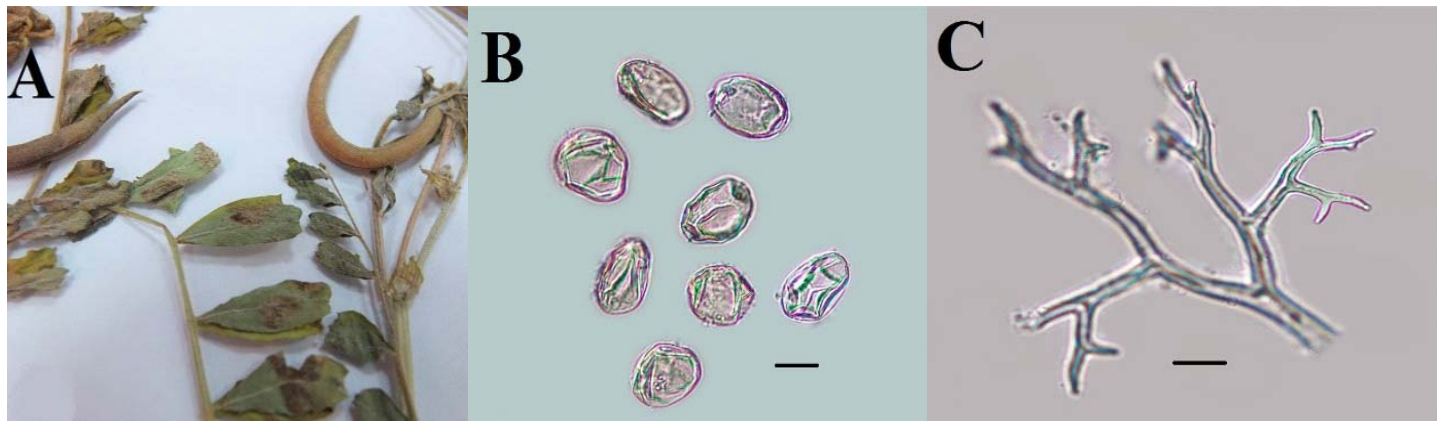

Figure 6 - Peronospora astragalina. A: Symptoms. B: Conidia. C: Ultimate branchlets. Bars: B 15 mm; C $25 \mu \mathrm{m}$.

Spots located mainly between the veins, yellowish-brown, irregular, 1.5-2 mm across. Conidial coating on lower, sometimes on the upper surface of leaves, loose, grayish-violet. Conidiophores hypophyllous, solitary or fascicled, 220-420 $\mu \mathrm{m}$ long, slender, colorless; trunk sub straight to slightly curved, 80-210 $\mu \mathrm{m}$ long, 5-11 $\mu \mathrm{m}$ wide below the first branch; branches dichotomously branched in three to six orders, slightly curved, almost straight; ultimate branchlets in pairs, situated at a right angle, unequal, straight to slightly curved, sometimes subulate, (5-)7.520(-25) $\mu \mathrm{m}$ long, 1.5-2.0 $\mu \mathrm{m}$ wide at the base, apex acute. Conidia slightly greyish-violet, ellipsoidal, broadly ellipsoidal, broadly rounded, $15-28$ x 12-26 $\mu \mathrm{m}$, mostly $17.5-25$ x 15-20 $\mu \mathrm{m}$, pedicel absent. Resting organs visible as greyish-violet dots on the lower leaf surface; oogonia oval, broadly ellipsoidal, 40-42 $\mu \mathrm{m}$ diam.; oospores almost globose, 30-36 $\mu \mathrm{m}$ diam., wall smooth, hyaline. 
Specimen examined: In lentils field, on the living leaves of Astragalus hamosus L. (Fabaceae), Turkey, Diyarbakir Province, 3766’37" N, 4196’65" E, 464 m, July 11, 2014. CÖ 201429.

Conidiophores of $P$. astragalina from Europe are 200-400 $\mu \mathrm{m}$ long, 5-8 $\mu \mathrm{m}$ wide; conidia $12-32 \times 9-26 \mu \mathrm{m}$, mostly $20-25 \times 19-22 \mu \mathrm{m}$; oogonia $38 \mu \mathrm{m}$ diam. and oospores $30 \mu \mathrm{m}$ diam. (Gäumann, 1923: 188). Conidia from Transcaucasia are 12-28 x 10-26 $\mu \mathrm{m}$, frequently $18-22 \mathrm{x}$ 15-19 $\mu \mathrm{m}$ (Uljanishchev et al., 1985). Conidiophores of this fungus in Turkey are slightly longer, conidia shorter, oogonia and oospores are larger.

\section{Peronospora myagri Mayor (Figure 7)}

Mayor (1962)

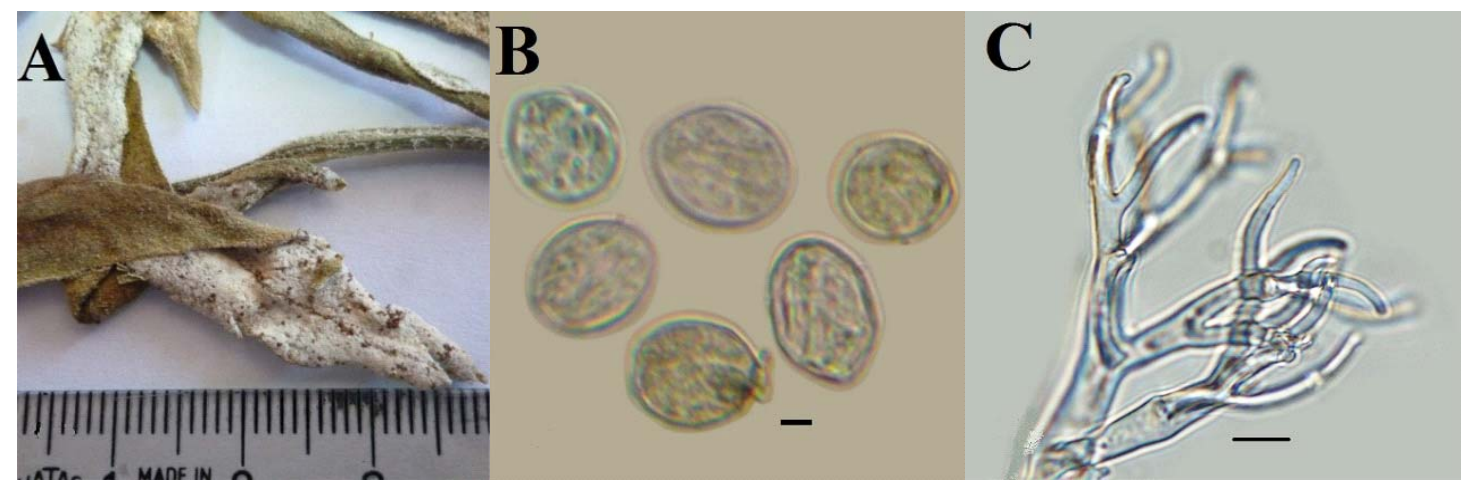

Figure 7 - Peronospora myagri. A: Symptoms. B: Conidia. C: Ultimate branchlets. Bars: B 5 mm; C $10 \mu \mathrm{m}$.

Conidial coating on stems and on lower surface of leaves which have corresponding yellow patches on their upper surface, dense, tomentose, white, whitish, greyish-white, almost entirely covered by a blade. On the stems, coating is greyish-white, scattered. Conidiophores $210-550 \mu \mathrm{m}$ long, slender, colorless; trunk straight to slightly curved, 125-400 $\mu \mathrm{m}$ long, 10-15 $\mu \mathrm{m}$ wide below the first branch; branches dichotomous, branched in four to six orders, straight to slightly curved; ultimate branchlets in pairs, situated at an acute angle, approximately equal, arcuate, sinuate, curvate, (7.5-)10-25 $\mu \mathrm{m}$ long, (1.5-) 2.0-2.5 $\mu \mathrm{m}$ wide at the base, apex obtuse or slightly rounded. Conidia colorless, oval, or ovate-ellipsoidal, rarely subglobose to globose, (19)20-25 x (15-)16$20 \mu \mathrm{m}$, pedicel absent in most conidia. Resting organs not seen.

Specimen examined: In lentils field, on the living leaves of Myagrum perfoliatum L. (Brassicaceae), Turkey, Diyarbakir Province, Çinar, 3769'10" N, 4049’50" E, 726 m, April 17, 2015. CÖ 201521.

Described by Mayor (1962) P. myagri from France has a shorter conidiophore (185-510 $\mu \mathrm{m}$, mostly 225-300 $\mu \mathrm{m}$ long), conidia (19-21 x 16-19 $\mu \mathrm{m}$ ), and a longer ultimate branchlets (16-38 $\mathrm{x}$ 2-2.5 $\mu \mathrm{m})$, than Turkish samples.

In the light of literature (Göbelez, 1963; 1964; Güven and Tamer, 1993; Ercis and Iren, 1993; Sahin and Tamer, 1998; Tamer et al., 1989, 1990, 1998; Tepe and Özrenk, 1999; Bahcecioglu and Gjaerum, 2003; Kavak, 2003; Sert and Sümbül, 2003; Kirbag, 2004; Sert, 2009; Tunali et al., 2009; Erdogdu et al., 2010; Ekici et al., 2012; Özaslan et al., 2013; Erdogdu and Hüseyin, 2013; Kavak and Bilgili, 2015; Özaslan et al., 2015) given on Turkish microfungi and Chromista, five microfungi and two Chromista species are new records for Turkey: Plectosphaerella alismatis, Pyricularia grisea, Phakopsora artemisiae, Puccinia rubefaciens, Ustilago trichophora, Peronospora astragalina and P. myagri. Plectosphaerella and Phakopsora are added to the fungal biota of Turkey as new records at generic level. Peronospora myagri described here represent the second collection of these species. Phakopsora artemisiae known hitherto from Japan, China, Pakistan, India, Taiwan, Korea, and Nepal (Hiratsuka, 1992; Khalid and Iqbal, 1996; Cho and Shin, 2004;), and P. myagri known from France on living leaves and stems of Myagrum perfoliatum (Mayor, 1962). 
The common broadleaf water weeds of agricultural crops are more serious problem than aquatic grassy weeds. Common water-plantain (Alisma plantago-aquatica), a semi-aquatic or aquatic perennial weed is the most troublesome weed in wild rice fields. The foxtails are members of the Setaria genus and are one of the worst weed groups interfering with North American and world agriculture and in other disturbed and managed habitats (Holm et al., 1977, 1979, 1997). The weedy Setaria spp. include S. viridis subspecies viridis (green foxtail), S. glauca (yellow foxtail), S. faberii (giant foxtail), S. verticillata (bristly foxtail) and S. geniculata (knotroot foxtail) (Pohl, 1951, 1966; Rominger, 1962). Artemisia dracunculus (tarragon) is a perennial herb in the Asteraceae (daisy) family. It also possesses a wide range of health benefits. Galium spp. (Galium aparine and Galium tricornutum) are the problem weeds of agricultural crops. Holm et al. (1991) described G. aparine as a serious or principal weed in 10 countries. Worldwide it has been reported as a weed of 19 crops in 31 countries (Holm et al., 1977). G. aparine is resistant to phenoxyacetic acid herbicides, and their widespread use, particularly in cereals, before the introduction of sulfonylureas was largely responsible for the increase in $G$. aparine distribution in many European countries (Rola, 1969; Bachthaler and Dancau, 1970; Pawlowski and Wszolek, 1978; Malik and van den Born, 1988). In cereals, Rola (1969) reported potential yield reductions of 30-60\%. Roder et al. (1990) found the yield decline caused by one $G$. aparine plant $\mathrm{m}^{-2}$ was $0.24 \%$ in winter barley and $0.14 \%$ in winter wheat. Trials in Turkey estimated economic thresholds for the control of G. aparine as 0.7-2.1 plants $\mathrm{m}^{-2}$ (Uygur and Mennan, 1996). Barnyardgrass (Echinochloa crus-galli) is found in 36 crops worldwide. It is the world's principal weed of rice, and is particularly serious weed in Australia, Brazil, Ceylon, Chile, Greece, Indonesia, Iran, Italy, Japan, Korea, Philippines, Portugal, Spain and Taiwan. It is among the three worst weeds in cotton in Australia, USSR and Spain; in corn in Australia and Yugoslavia; and in sugarbeets in the United States. It is a principal weed in many other crops and countries (Holm et al., 1977). E. crus-galli grows as a weed of waterways, swamps, wetlands and other damp habitats as well as roadsides, waste areas and disturbed sites altering successional processes and outcompeting native vegetation. This species has been listed as an environmental weed in Canada, the United States, Brazil and Australia, where it is ranked among the top 200 invasive plant species (Queensland Department of Primary Industry and Fisheries, 2011). Milkvetch (Astragalus hamosus) is widely distributed in Tunisia and in other parts of the world (Zoghlami and Zouaghi, 2003). A. hamosus is a hard droughttolerant plant potentially useful for soil protection in Mediterranean areas (Patane and Gresta, 2006). Bird's eye cress (Myagrum perfoliatum) considered a serious weed of broadleaf crops such as chickpeas, canola, lupins, faba beans, field peas and lentils. Bird's eye cress is considered a potential seed contaminant. It can create blockages during harvest. It has competed with agricultural crops, reducing crop yields by up to $50 \%$, it can smother cereal and canola (Storrie, 2014). Since Bird's eye cress tolerates many of the herbicides used in crops (Government of South Australia, 2014; Texas Invasives, 2013), control in agricultural crops is difficult.

Weeds in agricultural crops are one of the essential economic and agronomic problems of plant production. Traditional agricultural practices have generally focused on herbicides, mechanical, and cultural methods as the main tools for weed management. Although these methods have served crop production well, it is important to recognize that living organisms like insects, fungi, and bacteria as biological control agents for weed management. Some virulent pathogens on the weeds could lead to improved weed control by making the weed less vigorous and reducing its competitive ability. Phytopathogenic fungi are often used for biological weed control. Seven different fungi species have been identified in the current study on seven distinct weed species. These species; Plectosphaerella alismatis, Pyricularia grisea, Phakopsora artemisiae, Puccinia rubefaciens, Ustilago trichophora, Peronospora astragalina and P. myagri. Plectosphaerella and Phakopsora as generic level and others as species are new records from Turkey. These fungi species can be potential biologial control agenst of these weed species in the era of increasing concerns on environment safety and herbicide resistance. A useful and safe biocontrol agent has to be as specific as possible. However, detailed studies on host specificity and potential of these species to damage/control needs to be explored in detailed studies.

\section{ACKNOWLEDGMENTS}

We are thankful to Prof. Dr. Uwe Braun (Halle, Germany) for help in clarifying the specific accessory of Plectosphaerella alismatis and thanks are due to Prof. Dr. Cvetomir Denchev (Sofia, Bulgaria) for help through access to Vanky's European smut fungi and Smut fungi of the world. 


\section{REFERENCES}

Australia. Government of South Australia. Declared Plant Policy under the Natural Resources Management Act 2004: musk weed (Myagrum perfoliatum). 2014. 4p.

Azbukina Z. The rust fungi. (Lower plants, fungi and mosses of the Russian Far East. Fungi; 5). Vladivostok: Dalnauka; 2005.

Bachthaler G, Dancau B. Influence of production technique on the weed flora in sugarbeet, with particular regard to chemical weed control. In: Proceedings of the $2^{\text {nd }}$ International Meeting for Selective Weed Control in Beet Crops, Rotterdam: 1970. p.221-33.

Bahcecioglu Z, Gjaerum HB. New and rare rust fungi (Uredinales) from Anatolia (Turkey). Mycotaxon. 2003;85:165-173.

Braun U. A monograph of Cercosporella, Ramularia, and allied genera (phytopathogenic hyphomycetes). Ihw-Verlag Eching; 1998

Carlucci A, Raimondo ML, Santos J, Phillips AJ. Plectosphaerella species associated with root and collar rots of horticultural crops in southern Italy. Persoonia-Molec Phylog Evol Fungi. 2012;28:34-48.

COLUMA. Journées internationales sur la lutte contre les mauvaises herbes, Reims, France, 6-8 décembre 1995. Reims, France: 1996. p.347-54. Tome 1.

Cho W-D, Shin H-D. List of plant diseases in Korea. Korean Society of Plant Pathology, 2004.

Davis PH. Flora of Turkey and the East Aegean Islands. Edinburgh: Edinburgh University Press; ;1965-1985. 9v.

Dugan FM, Glawe DA. Powdery mildews on weeds in the Pacific Northwest: a miscellany of new records. North American Fungi. 2007;2:1-7.

Ekici T, Makbule E; Zeki A; Zekiye S. Septoria species in Kibris Village Valley (Ankara, Turkey). Nova Hedwigia. 2012;95:483-91.

Ellis MB, Ellis JP. Microfungi on land plants. An identification handbook. London: Croom Helm;1985.

Ercis A, Iren S. Some research on the biological control of weeds rust. Adana: Adana Plant Protection Research Institute; 1993. p.397-404. (In Turkish).

Erdogdu M, Hüseyin E. Records of microfungi associated with plants in the Kemaliye district, Erzincan, Turkey. Nova Hedwigia. 2013;97:441-56.

Erdogdu M, Hüseyin E, Suludere z. Description of the rusts from Kemaliye (Erzincan, Turkey). Phytoparasitica. 2010;38:81-93.

Fungorum I. Index fungorum. CABI, CBS and Landcare Research (custodians), [accessed 2016.15]

Gäumann E. Beiträge zu einer Monographie der Gattung Peronospora. Beiträge zur Kryptogamenflora der Schweiz. 1923;5(4):1360 .

Göbelez M. La mycoflore de Turquie. Mycopathologia. 1963;19:296-314.

Göbelez M. La mycoflore de Turquie. Mycopathologia. 1964;23:47-67.

Gutner LS. The Smut Fungi of the U.S.S.R. Leningrad: State Publishing Department, Section of Agriculture; 1941. (in Russian).

Güven K, Tamer A. Some parasitic fungi determined in plants living in Eskisehir. J Sci Ege University Series B. 1993;15:25-31.

Hiratsuka N. The rust flora of Japan. Tsukuba Shuppankai;1992.

Holm LG, Pancho JV, Herberger JP, Plucknett DL. A geographic atlas of world weeds. Malabar: Krieger Publishing Company; 1991.

Holm LG, Plucknett DL, Pancho JV, Herberger JP. The world's worst weeds distribution and biology. Honolulu: The East-West Food Institute; 1977. 
Holm LG, Holm L, Holm E, Pancho JV, Herberger JP. World weeds: Natural histories and distribution. New York: John Wiley \& Sons; 1997.

Holm LG, et al. A geographic atlas of world weeds. New York: Wiley-Interscience, John Wiley \& Sons; 1979.

Kavak H. First record of leaf scald caused by Rhynchosporium secalis in a natural population of Hordeum vulgare ssp. spontaneum in Turkey. Plant Pathol. 2003;52:805-5.

Kavak H, Bilgili A. First report of Puccinia dracunculina on Artemisia dracunculus in Turkey. New Dis Rep. 2015;31:28.

Khalid A, Iqbal S. New rusts from Pakistan. Can J Bot. 1996;74:506-8.

Kirbag S. New records of microfungi from Turkey. Pak J Bot. 2004;36:445-8.

Kirk P, Ansell A. Authors of fungal names, index of fungi supplement. JSTOR; 1993.

Kiss L. A review of fungal antagonists of powdery mildews and their potential as biocontrol agents. Pest Manag Sci. 2003;59:47583.

Kuprevich VU. VI. Guide to rust fungi of the USSR. 1. Fam. Melampsoraceae and some other genera of Fam. Pucciniaceae. Minsk: Nauka i Tekhnika; 1975.

Malik N, van den Born WH. The biology of Canadian weeds. 86. Galium aparine L. and Galium spurium L. Can J Plant Sci. 1988;68(2):481-99.

Mayor E. A propos d'un Peronospora sur Myagrum perfoliatum L. et d'un Puccinia sur Senecio vulgaris L. Büchler; 1962.

Mordue J. IMI descriptions of fungi and bacteria, set 125, nos. 1241-1250. Mycopathologia. 1995;131:39-61.

Mundkur BB. Indian species of Phakopsora and Bubakia. Mycologia. 1943;35:538-45.

Özaslan C, Erdogdu M, Hüseyin E, Suludere Z. Additions to rust and chytrid pathogens of Turkey. Mycotaxon. 2015;130:11-15.

Özaslan C, Hüseyin E, Erdogdu M. Microfungi species on the weeds of agro-ecosystem (wheat ecosystem) in Adiyaman City. Mantar Dergisi. 2013;4:10-8.

Patane C, Gresta F. Germination of Astragalus hamosus and Medicago orbicularis as affected by seed-coat dormancy breaks techniques. J Arid Environ. 2006;67:165-73.

Pawlowski F, Wszolek M. Weediness of the summer barley and winter wheat grain on loess and chernozem soils in the Hrubieszow region. Roczniki Nauk Rolniczych A. 1978;103(2):131-45.

Pohl RW. The genus Setaria in Iowa. IA St J Sci. 1951;25:501-8.

Pohl RW. The grasses of Iowa. IA St J Sci. 1966;40:341-73.

Queensland Department of Primary Industries and Fisheries. Special edition of Environmental Weeds of Australia for Biosecurity Queensland, Australia: The University of Queensland and Department of Primary Industries and Fisheries; 2011.

Rector BG, Harizanova V, Sforza R, WidmerT, Wiedenmann RN. Prospects for biological control of teasels, Dipsacus spp., a new target in the United States. Biol Control. 2006;36:1-14.

Roder W, Eggert H, Kalmus, A. Occurrence and detrimental effect of cleavers, Galium aparine L., in grain fields. Nachrichtenblatt Pflanzenschutz. 1990;44(11):253-6.

Rola J. Causes and effect of weed compensation in crops. C Biul Inst Ochr Roslin. 1969;44:409-24.

Rominger JM. Taxonomy of Setaria (Gramineae) in North America. Urbana: University of Illinois Press; 1962. (Illinois biological Monographs, 29)

Saccardo PA. Sylloge Hyphomycetum. Sylloge Fungorum. 1886;4:1-807. 
Saccardo PA. Sylloge Fungorum Omnium Hucusque Cognitorum. Johnson reprint corporation, 1881-1931.

Savulescu T. Ustilaginalele din Republica Populara Romina. Bucharest: 1957.

Sert HB. Additions to rust and smut fungi of Turkey. Phytoparasitica. 2009;37:189-92.

Sert HB, Sümbül H. Two new records of downy mildews (Peronosporaceae) in Turkey and a new host. Phytoparasitica. 2003;31:529-31.

Shvartsman S. Cryptogamic flora of Kazakhstan; Ustilaginales. Kazakhstan, Russia: Cryptogamic Flora of Kazakhstan; 1960. v.2.

Shvartsman SR, Vasyagina MP, Byzova ZM, Filimonova NM. Kazakhstan, Russia: Cryptogamic Flora of Kazakhstan; 1973.

Storrie AM editor. Integrated weed management in Australian Cropping Systems. $2^{\text {nd }}$. ed. Barton, Australia: Grains Research \& Development Corporation; 2014.

Sahin N, Tamer AÜ. Smut species determined in Turkey. J Turk Phytopathol. 1998;27:151-6.

Tamer AU, Altan Y, Gücin F. Some parasitic fungi determined on the flora of Gülveren Village (Erzurum-Senkaya). J Anadolu Univ Arts Sci Faculty. 1989;1:45-55. Journal of Anadolu University Arts and Sciences Faculty 1(2):

Tamer AÜ, Altan Y, Gücin F. Some parasitic fungi determined in flora of East Anatolian region. Turk J Bot. 1990;14:83-6.

Tamer AÜ, Sahin N, Ugurlu E. Rust fungi identified in Turkey. In:14 th Biological Congress. 1998. p.395-408.

Tepe I, Özrenk K. Study on determining pathogenic rust fungi on weeds in Van Province. Türkiye Herboloji Dergisi. 1999;2:17-24.

Texas Invasives. Myagrum perfoliatum L. (Bird's eye-cress). TexasInvasives.org. Last [accessed July 20, 2017]. Avaiable at: http:// www.texasinvasives.org/plant_database/detail_print.php?symbol=MYPE.

Tunali B, Yildirim A, Berner DK, Askin A, Aime C. Studies on the determination of the rust fungi on weeds. Plant Prot Bull. 2009;49:79-87.

Uljanishchev V. Guide to rust fungi of the USSR 2. 1968 382p.

Uljanishchev V. Guide to rust fungi of the USSR. 1978. 183p.

Uljanishchev VI, Osipyan LL, Kanchaveli LA, Akhundov TM. Guide to fungi of Transcaucasia. Peronosporales. Erevan: Erevan University Press; 1985.

Uygur FN, Mennan H. A study on economic Thresholds of Galium aparine L. and Bifora radians Bieb. in wheat fields in SamsunTurkey. Seizième conférence du

Vánky K. Smut fungi of the world. San Paul: American Phytopathological Society; 2012.

Zimdahl RL. Fundamentals of weed science. Academic Press; 2013.

Zoghlami A, Zouaghi M. Morphological variation in Astragalus hamosus L. and Coronilla scorpioides L. populations of Tunisia. Euphytica. 2003;134:137-47. 